DOI: 10.15290/rtk.2018.17.1.02

iD 0000-0001-6866-6165

Grzegorz Kamil Szczecina Katolicki Uniwersytet Lubelski Jana Pawła II

\title{
Bl. Fr. Jerzy Popieluszko's Patriotic Model: St. Maximilian M. Kolbe, the Martyr of Auschwitz-Birkenau
}

The moral messages that Bl. Jerzy Popieluszko's conveyed in the homilies that he gave during his famous "Masses for the Fatherland" are still relevant today, particularly with regard to fundamental issues concerning the values of man and society. Patriotism is among the many topics that this martyr addressed. Fr. Popieluszko looked up to St. Maximilian Maria Kolbe, OFM Conv, as a personal example of love and the gift of oneself to God and one's neighbor. St. Maximilian, otherwise known as the Martyr of Auschwitz-Birkenau, and his life, pastoral ministry, teaching, boundless charity, and self-offering for the Church and Poland were an inspiration to Fr. Jerzy. As he read the "Knight of the Immaculate" publications as a youth, the young future priest from Warsaw was fascinated with the Franciscan's life. Years later, the figure of St. Maximilian Maria Kolbe served to show Fr. Jerzy the importance of the virtue of patriotism in the life of every Christian, particularly Poles.

Key words: Jerzy Popieluszko, Maximilian Maria Kolbe, patriotism, moral teaching, martyrdom, "Mass for the Fatherland".

In one of their pastoral letters, the Polish bishops wrote the following about the virtue of love for one's country: "Patriotism is a wellunderstood love of one's Homeland [...] based on a deep attachment to that which is native to it, a belonging to time and space [...] Christian love for one's Homeland entails not only a concern for its greatest economic, social, and cultural development, but also for its spiritual 
Moral theology

and religious development." ${ }^{1}$ Patriotism increases in a particular way when external or internal enemies threaten one's Homeland-when dramatic and painful events unite a nation. At these moments, man is reminded of his obligation to pray for, care for, and serve his Homeland as he would his "mother." For centuries, the Church has been an integral element of Poland's history and statehood. Throughout the history of the Church in Poland, there has been no lack of witnesses whose lives, actions, and often martyrdom testify to their love for their Homeland-a love so great that they gave of their lives as a complete gift of self. St. Wojciech, Bishop and Martyr; St. Stanislaw of Szepanow, St. Andrew Bobola, St. Maximilian M. Kolbe, and Bl. Jerzy Popieluszko are among these national witnesses in whose lives is clearly reflected not only Poland's difficult history, but above all their love for God and their Homeland.

As stated above, Bl. Jerzy Popieluszko-the Martyr of Communism-is an exceptional figure among priests who devoted themselves to God, the Church, and Poland. ${ }^{2}$ The attitude, actions, and martyrdom of this courageous Polish priest are an integral element of Polish history, particularly during the 1980s. The homilies that Fr. Popieluszko gave during the monthly "Mass for the Homeland and for those who suffer

$1 \quad$ W trosce o człowieka i dobro wspólne. List na 200. rocznicę pierwszego rozbioru Polski, in Listy Pasterskie Episkopatu Polski 1945-1974, Paris 1975, pg. 707.

He was born on September 14, 1947 in Okopy near Suchowola in what is known today as the Diocese of Bialystok. From childhood, he was devoted and zealous in his love for God and neighbor. After graduating from high school in Suchowola in 1965, Fr. Jerzy entered the seminary in Warsaw. During his formation for the priesthood, he was called to compulsory military service for two years in Bartoszyce where, despite the military's harassment and mockery, he bravely distinguished himself in his closeness to God and the Church. Fr. Jerzy was ordained a priest in 1972. From 1980 onward, he served as a resident at the parish of St. Stanislaw Kostka in Warsaw. After the enforcement of martial law (1981-1983), Fr. Jerzy began to celebrate Masses for his homeland, which drew crowds of the faithful. In peaceful and straightforward homilies, he defended the dignity of man and the nation. Above all, he called Poles to give Christian witness in their difficult and painful situation. He organized assistance for the families of interned workers to whom he provided pastoral care. After being repeatedly harassed and persecuted by the communist authorities, he was abducted and murdered by the Security Police on October 19, 1984. Fr. Jerzy was beatified on June 6, 2010, and his canonization process began on September 20, 2014 in the Diocese of Creteli in France. G. K. Szczecina, Aktualność przestania moralnego bt. ks. Jerzego Popietuszki $w$ perspektywie przemian spotecznych w Polsce po 1989 roku, Nowy Sącz 2015, pgs. 21-54. See M. Kindziuk, Świadek prawdy. Życie i śmierć księdza Jerzego Popietuszki, Częstochowa 2010²; E. K. Czaczkowska, T. Wiścicki, Ksiądz Jerzy Popietuszko. Wiara, nadzieja, miłość. Biografia Błogostawionego, Warsaw 2017. 
the most for It,"3 which he celebrated in St. Stanislaw Kostka church in Warsaw from 1982-1984, ${ }^{4}$ were filled with the spirit of his love for God, the Church, and his neighbor. The main part of Fr. Popieluszko's ministry took place when the Communist leadership enforced martial law in Poland, marginalized the Solidarity opposition, and destroyed the fundamental human rights of the Polish people and nation. At that time, the St. Stanislaw Kostka church and the patriotic services that took place there drew thousands of faithful. These events sometimes served as a public witness of faith and always provided a reflection on the times in the spirit of the Gospel. "Masses for the Homeland" were a safe asylum and bastion of freedom, but most of all they provided opportunities for the faithful to quiet themselves and participate in deep prayer. ${ }^{5}$

\section{Childhood Fascination with a Conventual Franciscan}

An essential aspect of Bl. Jerzy Popieluszko's life was his patriotic formation. Fr. Jerzy (known as a child as Alfons) was brought up in the Podlasie region of Poland where the people are faithful, religious, and fond of their "small Homeland." The Popieluszko family came

$3 \quad$ This was the name of the monthly "Zoliborskie services.' The idea of the "Holy Mass for the Homeland" is rooted in Polish tradition. From the time of King Wladyslaw Jagiello, it became a custom of the Church to organize Mass and prayers for political intentions (often before important battles). Pope Clement XIII ordered three days of prayer for Poland in 1767 before the country was partitioned for the first time. During the national uprisings and partitions, there was a significant increase in the services "for the well-being of the fatherland." See J. Sochoń, Tama. Opowieść o życiu u męczeństwie księdza Jerzego Popietuszki, Cracow 2010, pgs. 125-126; J. Komar, Warszawskie manifestacje patriotyczne 1860-1861, Warsaw 1970, pgs. 189-193n.

4 Fr. Teofil Bogucki initiated the "Holy Mass for the Homeland" at St. Stanislaw Kostka parish in October 1980. From February 1982, the Masses were held regularly on the last Sunday of every month. Fr. Bogucki subsequently entrusted the celebration of the Masses, homilies, and all of the organizational preparation to Fr. Jerzy Popieluszko. The homilies that Fr. Jerzy gave for the "Masses for the Homeland" that occurred from January 1982 to September 1984 were transcribed and published. A total of 26 homilies serve as sources for Bl. Jerzy's moral teaching. His prayerful meditations prepared for the Way of the Cross, the recitation of the Rosary, and his homilies were broadcast in several Polish cities. Por. Z. Malacki, Świadek trudnych czasów, in Ksiadz Jerzy Popiełuszko. Kazania 1982-1984, Z. Malacki (ed.), Warsaw 2004, pgs. 6-7; G. K. Szczecina, Aktualność przestania..., op. cit., pgs. 55-90; A. Mularska, Święty wśród nas. Błogostawiony ksiądz Jerzy Popietuszko, Cracow 2015, pgs. 344-348. 
Moral theology

from a line of patriotic ancestors. ${ }^{6}$ Fr. Jerzy's uncle, Alfons Gniedziejko was a soldier in Poland's Home Army and died in $1945 .{ }^{7}$ While Alek (Fr. Jerzy) learned to love his Homeland as he grew up in his family home ${ }^{8}$ his fascination with St. Maximilian Kolbe-the Martyr of Auschwitz-Birkenau-was an important element in his religious and patriotic development. ${ }^{9}$ This Franciscan, whose extremely rich life and dedicated service, particularly in his witness to his infinite love for God and man, served as a personal moral example to Fr. Jerzy from his childhood onward. Bl. Jerzy Popieluszko's mother said the following on this topic: "Ever since [Alek] was young, he was very close to us. When he was a child, he liked to stay with his grandmother. When someone from Okopy went to Grodzisk, he would jump on the wagon and get a ride to his grandmother's [home]. He loved to look at her

$6 \quad$ According to Fr. Popieluszko's family records, Marianna Gniedziejko's (Marianna Popieluszko's mother) uncle was Saint Rafal (Jozef) Kalinowski who died in 1907. He was a Carmelite who was beatified by John Paul II in Cracow in 1983, and canonized in Rome in 1991. Before joining the monastery, he took part in the January Uprising and was deported to Siberia. According to family legend, Marianna Popieluszko's brother, Alfons Gniedziejko, fought in the Home Army and died at the age of twenty-one. As told by J. Popieluszko (private collection); related by T. Boguszewska (z.d. Popiełuszko), private collection; related by Fr. K. Gniedziejko, (private collection); related by J. Kopańko (private collection); related by K. Kopańko (private collection). See also: A. Mularska, Święty wśród nas..., op. cit., 23-24.

7 Related by Capt. B. Karwowski (a.k.a. "Grom") (private collection); related by Fr. K. Gniedziejko (private collection). Por. E. Gabrel, Suchowola. Jej przesztość i teraźniejszość, Suchowola 2012, pgs. 244-246; Traktowatem Go jak starszego brata - rozmowa z ks. Kazimierzem Gniedziejka, in Modlitwa za Polskę. Ksiadz Jerzy Popietuszko we wspomnieniach bliskich, P. Czartoryski-Sziler (ed.), Szczecinek 2004, pgs. 39-40.

See Błogosławiony Jerzy Popietuszko. Zapiski, listy i wywiady ks. Jerzego Popietuszki 1967-1984, G. Bartoszewski (ed.), Warsaw 2010.

He was born in 1894 in Zdunska Wola. As a Conventual Franciscan, he was involved in pastoral and missionary activities. He founded and built the Niepokalanow monastery, which was to serve as a modern center for Catholic media. Through his initiative, the magazine Knight of the Immaculata was created, which is still being published today. Between 1931-1935, he served as a missionary in Japan, where he also published the Knight of the Immaculata and established a monastery according to the example of the Polish monastery Niepokalanow. Thanks to him, such centers were also established in China and India. Fr. Maximilian also founded the religious order of the Knights of the Immaculate. He died a martyr's death by offering his life in the place of a fellow prisoner in the Auschwitz-Birkenau extermination camp on August 14, 1941. Paul VI beatified Maximilian Kolbe, and Pope John Paul II canonized him in 1982. S. Napiórkowski, Maksymilian Kolbe, in Encyklopedia katolicka, E. Ziemann (ed.), vol. 11, Lublin 2006, k. 915-918. 
religious magazines, and he would place the Knight of the Immaculata magazines in a pile and continue to read them. Ever since then, [Alek] spoke a lot about Fr. Maximilian Kolbe, who was his role model."10

As he read the Knight of the Immaculata magazine published by the Franciscans of Niepokalanow, an order founded by St. Maximilian Kolbe, the young Jerzy Popieluszko became more and more familiar with St. Maximilian. Uncle Alfons was the one who had begun subscribing to these magazines in the pre-war period, which inspired the future Bl. Jerzy so much. ${ }^{11}$ The influence that this publication had on Fr. Jerzy also testifies to the scope and influence that it had on the faithful in general. At that time, Knight of the Immaculata magazine was a source of information about the life of the Church and the problems of modern man. Today Fr. Jerzy's copies of these publications can be found close to his relics in Zoliborz in the museum located in basement of the church where Bl. Jerzy served. These magazines contain interesting lessons and information that young Alfons (Jerzy) had to have encountered. For example, the publications contain articles about the lives of the saints (especially St. Francis of Assisi) as well as current affairs in the Church and in the world. Undoubtedly, they brought to life Maximilian Kolbe's activity. ${ }^{12}$ The magazines published after the war focused primarily on St. Maximilian's life, especially his love for his Homeland and God, as well as the circumstances surrounding his martyrdom, all of which served to form the real and spiritual foundation of Bl. Jerzy's patriotic and religious personality.

Bl. Jerzy mother, Marianna Popieluszko, mentioned that the young Alfons' youthful fascination with St. Maximilian was so great that he expressed a desire to enter the Franciscan order in Niepokalanow when he grew up. Certainly, the influence of the Franciscan Br. Colomban Emil Jaroszewicz, ${ }^{13}$ who also came from the parish in Suchowola,

10 M. Kindziuk, Matka świętego. Poruszające świadectwo Marianny Popietuszko, Cracow 2012, pgs. 57-58.

11 "My brother, who was killed, frequently received the Knight of the Immaculata [magazine]. Jerzy found it at my mother's house, he collected everything, framed them, and read these magazines. He did this in primary school." Zgadzatam się z wola Boża. Rozmowa z Marianna Popietuszko, mama księdza Jerzego, in Ks. Jerzy Popietuszko. Syn, kapłan, męczennik, P. Burgoński, C. Smuniewski (ed.), Warsaw 2010, pg. 25. Related by Fr. K. Gniedziejko (private collection).

12 See "Rycerz Niepokalanej," 12(1933), no. 11(43); 12(1934), no. 12(156); 15(1936), no. 4(172), 18(1939), no. 1(205), 27(1948), no. 1(245), no. 19(1945), no. 2(216).

13 Brother Kolumban Emil Jaroszewicz (1911-2003) was born in Grzymiaczki (Suchowola parish) and entered the monastery in Niepokalanow in 1935 . He was a close associate of St. Maximilian Kolbe and worked on printing the 
Moral theology was significant. ${ }^{14}$ Alfons kept in continual contact with him, and even when Fr. Jerzy was serving in parishes in Warsaw, he would often visit Niepokalanow in order to spend time with his fellow countryman. ${ }^{15}$ However, in the end, Fr. Jerzy chose to enter the seminary in Warsaw, which was under the direction of the Primate of Poland Cardinal Stefan Wyszynski, ${ }^{16}$ since it was still close to Niepokalanow: "He wanted to go to Niepokalanow. And he probably chose the seminary in Warsaw because of [its close proximity to] Niepokalanow. Later I noticed that he wore the belt of St. Francis. He spoke a lot about Fr. Maximilian Kolbe..." ${ }^{17}$ In the Popieluszko family reminiscences, they often mention the fact that the young Alek (Fr. Jerzy) would show a slideshow in his family home depicting the life and activity of the "martyr of World War II." 18 Often gatherings drew the neighbors, to whom the future martyr invariably spoke about the life of the Martyr of Auschwitz-Birkenau. It is not surprising, therefore, that Alfons frequently visited Niepokalanow during his seminary studies. During his priestly formation, Alfons also became a Third Order Franciscan. ${ }^{19}$

The Franciscan spirituality and profile of St. Maximilian M. Kolbe, in whose shadow the future Martyr of Communism grew and matured, was one of the first moral elements of Alfons' formation. Knowing St. Maximilian's life and ministry very well, Alfons Popieluszko grew up not only in a religious atmosphere and spirit and with a special devotion to the Immaculate, but he also knew the history of Poland and the story of St. Maximilian, whose courage, humility, devotion, and attitude served as a moral example of what it looks like to fully live

Knight of the Immaculata publication. (Information provided in the obituary of Br. Kolomban Emil Jaroszewicz contained in the Monastery Archive of the Conventual Franciscans in Niepokalanow, n. d.).

14 "Then they urged him a little to go to Niepokalanow because Jaroszewicz, who was from our parish, was there." Zgadzatam się z wola Boża. Rozmowa z Marianna Popietuszko, mama księdza Jerzego, in Ks. Jerzy Popietuszko..., op. cit., pg. 25.

Ł. Janicki, Bt. Jerzy Popietuszko i Niepokalanów. Św. Maksymilian pociagat bt. Jerzego, "Posłaniec św. Antoniego," 18(2013), no. 1, pg. 17.

"Ileż ten chtopak przecierpiat:" Księdza Jerzego Popietuszke wspomina jego katecheta i spowiednik ks. kanonik Piotr Bożyk, "Wiadomości KAI," 43(2001), no. 43, pgs. 12-13. Related by Fr. P. Bożyka (private collection).

Cited in: S. Pastuszewski, Wybierat się do Niepokalanowa..., "Rycerz Niepokalanej," 2(1985), no. 344, pg. 43.

Odczuwat mitość do ottarza. Rozmowa z Marianna Popietuszko, matka Księdza Jerzego, in Modlitwa za Polskę..., op. cit., pg. 30. 
one's vocation as a Christian, religious, priest, and patriot. Therefore, it makes sense that Fr. Popieluszko would refer directly to St. Maximilian M. Kolbe as an example of love for God and for one's neighbor in Moral theology his homilies years later.

\section{An Example of Patriotism}

A fundamental aspect of Bl. Jerzy Popieluszko's ministry and activity were his service among workers and offering "Masses for the Homeland," during which he gave homilies that became famous not only in Poland, but also abroad. In his moral teaching, Fr. Jerzy provided personal examples of national heroes whose stories have been recorded in the annals of Polish history along with those who heroically loved God, the nation, and the Poland, often to the point of giving their lives for it. According to Fr. Popieluszko, Romuald Traugutt, the last leader of the January Uprising (1863-1864), ${ }^{20}$ and Fr. Maximilian Kolbe ${ }^{21}$ were particularly appealing examples of love for God and one's Homeland. St. Maximilian Kolbe's attitude, patriotism, and especially boundless charity towards others were the virtues that Fr. Popieluszko presented to the faithful who sought to be renewed in God and the Church during the difficult times and realities of the Communist terror that had cast its shadow over Poland.

On October 31, 1982, while celebrating a monthly "Mass for the Homeland," Fr. Jerzy Popieluszko spoke about the newly-canonized

20 Romuald Traugutt was born in 1826. From 1845, he served in the ranks of the Russian army. He participated in the Hungarian campaign, and in 1854 in the Crimean War. At the outbreak of the January Uprising, he took command of a unit fighting in Polesie in Kobryn. The National Government appointed him a general. On October 17, 1863, he was appointed the leader of the uprising. As part of the tsarist repression, he was murdered on the slopes of the Warsaw Citadel on August 5, 1864. Por. R. Bender, Traugutt Romuald, in Encyklopedia Katolicka, E. Gigilewicz (ed.), vol. 19, Lublin 2013, k. 994-996; See also: J. Popiełuszko, Homilia z 29 stycznia 1984 r., in Kazania 1982-1984. Wygtoszone w kościele św. Stanistawa Kostki w Warszawie. Bt. ksiądz Jerzy Popietuszko, G. Bartoszewski (ed.), Warsaw 2010, pgs. 164-171.

In his homilies, Fr. Popiełuszko recalled the examples of such Polish historical figures as: King Jan Kazimierz, Jan III Sobieski, Augustyn Kordecki, Tadeusz Kosciuszko, Bishop Stanislaw Okoniewski, Jozef Pilsudski, Stanislaw Witkiewicz, Pawel Wlodkowic, Stefan Zeromski, and General Jozef Hauke-Bosak. Por. J. Popiełuszko, Homilia z 30 maja 1982 r., op. cit., pg. 32; Homilia z 29 maja 1983 r., pg. 101; Homilia z 30 stycznia 1983 r., pg. 71; Homilia z 24 kwietnia 1983 r., pg. 90.; Homilia z 30 października 1983 r., pgs. 139-146; Homilia z 25 września 1983 r., pg. 134; Homilia z 29 stycznia 1984 r., pg. 164. 
Moral theology

St. Maximilian Kolbe ${ }^{22}$ as a valiant model of unbounded faithfulness to God and heroic love for one's neighbor, even in the terrible conditions of the concentration camp Auschwitz-Birkenau where people were enslaved and despised..$^{23}$ In his homily, Fr. Jerzy turned to St. Maximilian in prayer and said: "Today we stand at the altar of Christ and look at your image [...], Patron of a tormented Poland. [...] We stand here to offer our prayer at the throne of God, so that through your intercession you may enter into a dialogue with God on our behalf and on behalf of all those who suffer in camps and prisons, who suffer in the fight for justice and truth in our Homeland. [... We] include you among the saints, Fr. Maximilian, a contemporary martyr. Affirm us in the conviction that the power of evil, deception, contempt, and hatred for man must be overcome. You, St. Maximilian, are a symbol of the victory of someone who is enslaved, but who remains free in spirit." ${ }^{4}$ The figure of this great saint also helped Fr. Jerzy point out the virtue of truth, which is the foundation of a Christian life. He recalled and described St. Maximilian's freedom of spirit when he said: "In order to become free spiritually, it is necessary to live in the truth. To live in the truth is to give witness to the truth exteriorly-it is to profess it and proclaim it in every situation. Truth is immutable. Truth cannot be destroyed by one or another decision or law. Our enslavement lies in the fact that we give into lies, and we do not unmask them and protest against them each day. [...] Witnessing courageously to truth is the way that leads directly to freedom. The person who witnesses to the truth is free even when he is enslaved exteriorly, even in a prison camp or prison." 25

In his patriotic teaching, the aim of which was to form in people the virtue of love for God and their Homeland, ${ }^{26}$ the Martyr of Communism presented St. Maximilian as a moral example of someone who overcame fear and was ready to give even his life, if necessary, to defend

The canonization took place in Rome on October 10, 1982.

See A. Lewek, Kaznodziejstwo patriotyczne ks. Jerzego Popietuszki, "Ateneum kapłańskie," 143(2004), pg. 489. Ibid, pgs. 54-55.

26 See T.Zadykowicz, Umitowanie ojczyzny i patriotyzm, in Etykażotnierska. Etyka w stużbie ojczyźnie, K. Jeżyna, J. Gałkowski, M. Kalinowski (ed.), Warsaw 2008, pgs. 73-85; T. Zadykowicz, Patriotyzm jako postawa, in Etyka żotnierska..., op. cit., pgs. 53-58. 
Christian values because of his love for God and for his Homeland. ${ }^{27}$ When preaching in Zoliborz, Fr. Jerzy said:
You, St. Maximilian [...] were not afraid to go to unknown Japan to an- nounce the truth about Christ. You were not afraid to suffer and to lose your life. Because of this, your free spirit lives and bears fruit. [...] We need you so much, St. Maximilian, as an example of someone who did not give into fear and intimidation. We need you as a saint who we can call the patron of tormented Poland. For, which of the other saints could intercede for our enslaved nation more than you, who were beaten and despised-who looked upon your frightened brothers imprisoned with you in the camp and starvation bunker? Who better than you, who were taken to the prison camp unjustly and without cause, simply because you were among those of Poland's sons who loved her and loved the truth so much that you took on suffering and died so that someone else could live? To voluntarily accept suffering for another person is more than just suffering; for, only those who are interiorly free can make such a decision. ${ }^{28}$

In Fr. Jerzy's teaching, St. Maximilian M. Kolbe is a perfect and ideal example of what sacrificial patriotism and defending the dignity of human life looks like. ${ }^{29}$ In the homilies that Fr. Jerzy's gave in Zoliborz, the Martyr of Auschwitz-Birkenau is a symbol of the victory that someone who is physically enslaved but free in spirit can achieve. ${ }^{30}$

The patriotic celebrations in Warsaw typically included artistic, musical, and poetic elements. For example, the people created a figured of St. Maximilian Kolbe for the Mass celebrated on October 31, 1982. ${ }^{31}$ A board split into two parts was placed on the left side of the presbytery. On the higher board St. Maximilian was depicted in the prison camp denim uniform standing behind barbed wire. Where the saint's heart is located was the outline of Poland filled in with lines that resembled the fabric of the clothing that the prisoners wore in Auschwitz. Fr. Kolbe's prisoner number was place on the map of Poland and served as an expression of the nation's suffering and difficult history. The barbed wire was included as a symbol of St. Maximilian's imprisonment. On the lower part of the decorations, St. Maximilian Kolbe was presented as an advocate for suffering and imprisoned Poles, which was depicted in at the bottom of the image where the words "Patron of

\footnotetext{
27 J. Popiełuszko, Homilia z 25 marca 1984 r., op. cit., pg. 184.

28 J. Popiełuszko, Homilia z 31 października 1982 r., op. cit., pgs. 56-58.

See A. Lewek, Kaznodziejstwo patriotyczne..., op. cit., pgs. 488-490.

See G. K. Szczecina, Aktualność przesłania..., op. cit., pgs. 56-79. 
Moral theology

Tormented Poland" were written in so-called white "Solidarity" font on a red background..$^{32}$ All of the decorations were prepared in the national colors of Poland (red and white), and everything corresponded with the reality of the current communist oppression and martial law. Most importantly, Fr. Jerzy gave a homily, during which he presented St. Maximilian as a patron of Poland and Poles as well as a relevant model for their current situation.

The following letter that an individual wrote to the parish in Zoliborsk on October 31, 1982 expresses Fr. Jerzy's moral teaching as well as his references to St. Maximilian M. Kolbe as an ideal patriot and man who fully lived according to the Christian virtues: "The Masses that he celebrates each month make a lasting impression and are a source of continual reflection. The homilies that Fr. Jerzy gives command us to forgive our enemies and rid ourselves of every form of hatred. [...] My wife and I go to these Masses, and we are always moved. He refers to St. Maximilian Kolbe as an example of how to forgive one's enemies. After the attempt on his life, the Holy Father [Pope John Paul II] immediately forgave his assassin. Even though he had suffered for so long, [the Holy Father] did not hold a grudge against the man. In turn, the assassin himself regretted what he had done. And we ordinary people—should we behave any differently? This is what Fr. Popieluszko taught us through his celebrations of the Holy Mass and homilies." 33

For Bl. Jerzy Popieluszko, St. Maximilian M. Kolbe was an inspiration and example of how to live, serve, teach, and love one's homeland. Although the two men lived and worked in completely different sociopolitical conditions and contexts, there are many things that connect their lives, including their Franciscan spirit, their Marian devotion, their readiness to offer their lives for their neighbor, their love for their vocations, their service to the Church, their perseverance in suffering, their ability to endure in adversity, and, above all, their infinite love for Poland to the point of martyrdom. Bl. Jerzy Popieluszko's childhood fascination with the life of St. Maximilian Kolbe influenced his attitude and decisions later in life. The Martyr of Auschwitz-Birkenau expressed his patriotism in his selfless love for his neighbor and Homeland as well as in his defense of the dignity of human life, a topic to which Fr. Popieluszko dedicated a much his teaching. It was in St. Maximilian's life that Bl. Jerzy Popieluszko found a model to follow.

\footnotetext{
32 This is the characteristic font of the Solidarity logo in Polish. The shape of the letters resembles the workers who lean on and support each other.

33 P. Milcarek, Jerzy Popietuszko..., op. cit., pg. 118.
} 
And, in following St. Maximilian's example, Fr. Jerzy realized his love for God, the Church, and Poland; defended fundamental values even to the point of death; and presented the Church with another timeless model of the Christian life.

\section{MĘCZENNIK Z KL AUSCHWITZ-BIRKENAU - ŚW. MAKSYMILIAN M. KOLBE PATRIOTYCZNYM WZOREM DLA BŁ. KS. JERZEGO POPIEŁUSZKI}

Przesłanie moralne bł. ks. Jerzego Popiełuszki zawarte w Jego kazaniach, które wygłosił w trakcie słynnych „Mszy św. za Ojczyznę", jest wciąż aktualne, również w kwestii podstawowych wartości człowieka i społeczeństwa. Wśród wielu tematów, które podejmował męczennik komunizmu znalazło się również zagadnienie patriotyzmu. Jednym z osobowych wzorów, którego ukazywał ks. Popiełuszko jako przykład umiłowania oraz oddania się Bogu, bliźniemu i Ojczyźnie, był św. Maksymilian M. Kolbe. Ofiara obozu koncentracyjnego Auschwitz-Birkenau w Oświęcimiu dla ks. Jerzego była inspiracją w życiu, posłudze duszpasterskiej, nauczaniu i bezgranicznej miłości, ofiarności Kościołowi i Polsce. Już w latach wczesnej młodości przyszły warszawski kapłan dzięki lekturze pisma „Rycerz Niepokalanej" zafascynował się życiem franciszkanina. Jego postać po latach posłużyła mu do ukazania ważności prawidłowo rozumianej cnoty patriotyzmu w życiu każdego chrześcijanina, zwłaszcza Polaka.

Słowa kluczowe: Jerzy Popiełuszko, Maksymilian Kolbe, patriotyzm, nauczanie moralne, męczeństwo , „Msze św. za Ojczyznę".

\section{Bibliography:}

1. "Ileż ten chłopak przecierpiat": Księdza Jerzego Popietuszkę wspomina jego katecheta i spowiednik ks. kanonik Piotr Bożyk, "Wiadomości KAI", 43(2001), no. 43, pgs. 12-13.

2. "Rycerz Niepokalanej" 12(1933), no. 11(43).

3. "Rycerz Niepokalanej" 12(1934), no. 12(156).

4. "Rycerz Niepokalanej" 15(1936), no. 4(172).

5. "Rycerz Niepokalanej" 18(1939), no. 1(205).

6. "Rycerz Niepokalanej” 19(1945), no. 2(216).

7. "Rycerz Niepokalanej” 27(1948), no. 1(245).

8. Bender R., Traugutt Romuald, in Encyklopedia Katolicka, E. Gigilewicz (ed.), vol. 19, Lublina 2013, col. 994-996.

9. Błogosławiony Jerzy Popiełuszko. Zapiski, listy i wywiady ks. Jerzego Popietuszki 1967-1984, G. Bartoszewski (ed.), Warsaw 2010. 
Moral theology

10. E. K. Czaczkowska E. K., Wiścicki T., Ksiądz Jerzy Popiełuszko. Wiara, nadzieja, miłość. Biografia Błogosławionego, Warsaw 2017.

11. Encyklopedia Popularna PWN, B. Petrozolin-Skowrońska (ed.), 20 th Edition, Warsaw 1997, pgs. 804-805.

12. Gabrel E., Suchowola. Jej przeszłość i teraźniejszość, Suchowola 2012.

13. Janicki Ł., Bt. Jerzy Popietuszko i Niepokalanów. Św. Maksymilian pociagat bł. Jerzego, "Posłaniec św. Antoniego" 18(2013), no. 1, pg. 17.

14. Kazania 1982-1984. Wygłoszone w kościele św. Stanistawa Kostki w Warszawie. Bt. ksiadz Jerzy Popietuszko, G. Bartoszewski (ed.), Warsaw 2010.

15. Kindziuk M., Matka świętego. Poruszajace świadectwo Marianny Popietuszko, Cracow 2012.

16. Kindziuk M., Świadek prawdy. Życie i śmierć księdza Jerzego Popietuszki, Czestochowa 2010².

17. Komar J., Warszawskie manifestacje patriotyczne 1860-1861, Warsaw 1970.

18. Lewek A., Kaznodziejstwo patriotyczne ks. Jerzego Popietuszki, "Ateneum kapłańskie," 143(2004), pgs. 476-493.

19. Madała T., "Rycerz Niepokalanej," in Encyklopedia katolicka, E. Gigilewicz (ed.), Lublin 2012, col. 652-653.

20. Malacki Z., Świadek trudnych czasów, in Ksiądz Jerzy Popietuszko. Kazania 1982-1984, Z. Malacki (ed.), Warsaw 2004, pgs. 3-8.

21. Milcarek P., Jerzy Popietuszko. Kapłan Miłości, Warsaw 2014.

22. Mularska A., Święty wśród nas. Błogostawiony ksiądz Jerzy Popietuszko, Cracow 2015.

23. Napiórkowski S., Maksymilian Kolbe, in Encyklopedia katolicka, E. Ziemann (ed.), vol. 11, Lublin 2006, k. 915-918.

24. Obituary of Br. Kolumban Emil Jaroszewicz, Monastery Archive of the Conventual Franciscans in Niepokalanow.

25. Odczuwat miłość do ottarza. Rozmowa z Marianna Popiełuszko, matka Księdza Jerzego, in Modlitwa za Polskę. Ksiądz Jerzy Popietuszko we wspomnieniach bliskich, P. Czartoryski-Sziler (ed.), Szczecinek 2004, pgs. 27-34.

26. Pastuszewski S., Wybierat się do Niepokalanowa..., "Rycerz Niepokalanej," 2(1985), no. 344, pg. 43.

27. Relation by F. P. Bożyka, private collection.

28. Relation by J. Kopańko, private collection.

29. Relation by K. Kopańko, private collection.

30. Relation by Capt. B. Karwowski (aka "Grom"), private collection.

31. Relation by Fr. K. Gniedziejko, private collection.

32. Relation by T. Boguszewska (z.d. Popiełuszko), private collection.

33. Relation by J. Popiełuszko, private collection.

34. Sochoń J., Tama. Opowieść o życiu u męczeństwie księdza Jerzego Popietuszki, Cracow 2010.

35. Szczecina G. K., Aktualność przesłania moralnego bł. ks. Jerzego Popiełuszki $w$ perspektywie przemian społecznych $w$ Polsce po 1989 roku, Nowy Sacz 2015.

36. Traktowatem Go jak starszego brata - rozmowa z ks. Kazimierzem Gniedziejka, in Modlitwa za Polskę..., op. cit., pgs. 37-44. 
37. W trosce o człowieka i dobro wspólne. List na 200. rocznicę pierwszego rozbioru Polski, in Listy Pasterskie Episkopatu Polski 1945-1974, Paris 1975, pgs. 705-709.

38. Wielcy Polacy. Jerzy Popietuszko. Męczennik za wiare, J. Dowgiałło-Tyszka (ed.), Warsaw 2007.

39. Zadykowicz T., Patriotyzm jako postawa, in Etyka żotnierska. Etyka w stużbie ojczyźnie, K. Jeżyna, J. Gałkowski, M. Kalinowski (eds.), Warsaw 2008, pgs. 53-58.

40. Zadykowicz T., Umiłowanie ojczyzny i patriotyzm, in Etyka żotnierska.., op. cit., pgs. 73-85.

41. Zgadzatam się z wola Bożą. Rozmowa z Marianna Popietuszko, mama księdza Jerzego, in Ks. Jerzy Popiełuszko. Syn, kapłan, męczennik, P. Burgoński, C. Smuniewski (eds.), Warsaw 2010, pgs. 17-53. 